\title{
Art, Music, and Identity in the Global Era
}

\author{
Tomas Ondrusek \\ Academy of Performing Arts \\ University of Osijek, Czech Republic \\ email: ondrusek.tomas@gmail.com
}

\begin{abstract}
This paper investigates the interconnections between art as a cultural phenomenon and identity as a social phenomenon. Focused on the changes art and identity are going through in global era, it is divided into two sections: the cultural experience and the intercultural experience. Understanding both this forces, we investigate the challenges coming with the global era. Global era makes high-speed connection affordable at low-cost: Humans have access to information, but also access to physical move in the world through affordability of international transportation. Globalization brought incredible changes in the life of humans. It gives the possibility of first hand experience of the diversity in the world and makes intercultural experience accessed. A global citizen is a moving citizen, a person experiencing different countries and cultures. But: will these global citizens also in future have there own "global culture." We are dealing with a big paradox: on one side we have the era of globalization which produced already the first global citizens. On the other side we have art and creativity, which cannot exist without (local) cultural identity and which can even not be recognized out of their own culture as such and often seems funny or ridiculous. Art is deeply rooted in - and connected to - the local culture or cultural circle: like a flower, art creativity is growing in the soil of local culture: it uses signs, grammar, semantics, emotions and intellectual associations understood only by members socialized in a common cultural environment.
\end{abstract}

Keywords: art, music, identity, global era.

\section{ABSTRAK}

Tulisan ini meneliti keterkaitan antara seni sebagai fenomena budaya dan identitas sebagai fenomena sosial. Berfokus pada perubahan seni dan identitas yang terjadi di era global, tulisan ini dibagi menjadi dua bagian: pengalaman budaya dan pengalaman antarbudaya. Memahami kedua kekuatan ini, kita menyelidiki tantangan yang datang dengan era global. Era global membuat koneksi berkecepatan tinggi terjangkau dengan biaya rendah: Manusia memiliki akses ke informasi, tetapi juga akses ke pergerakan fisik di dunia melalui keterjangkauan transportasi internasional. Globalisasi membawa perubahan luar biasa dalam kehidupan manusia. Ini memberikan kemungkinan pengalaman tangan pertama dari keragaman di dunia dan membuat pengalaman antarbudaya dapat diakses. Warga global adalah warga negara yang bergerak, seseorang yang memiliki pengalaman berbagai negara dan budaya. Tetapi: apakah warga global ini juga di masa depan akan memiliki "budaya global" di sana. Kita berhadapan dengan paradoks besar: di satu sisi kita memiliki era globalisasi yang telah menghasilkan warga global pertama. Di sisi lain kita memiliki seni dan kreativitas, yang tidak mungkin ada tanpa identitas budaya (lokal) dan bahkan tidak disadari oleh kebudayaan di luar kebudayaan dirinya karena sering 
tampak lucu atau menggelikan. Seni berakar dalam - dan terhubung dengan budaya lokal atau lingkaran budaya: seperti bunga, kreativitas seni tumbuh di tanah budaya lokal: ia menggunakan tanda, tata bahasa, semantik, emosi, dan asosiasi intelektual yang hanya dipahami oleh anggota yang disosialisasikan di lingkungan budaya bersama.

Kata kunci: seni, musik, identitas, era global.

\section{INTRODUCTION}

Global era - this is our time, is where high-speed connection is affordable at low-cost. This means: access of information, but also access of physical move in the world through affordability of international transportation. Globalization brought incredible changes in the life of humans. A global citizen is a moving citizen, a person moving through different countries and cultures. But: will these global citizens also in future have there own "global culture"?

We are dealing with a big paradox: on one side we have the era of globalization which produced already the first global citizens. And on the other side we have art and creativity, which cannot exist without (local) cultural identity. Which can even not be recognized out of their own culture and often seems funny or ridiculous. Art is deeply rooted in - and connected to - the local culture or cultural circle: like a flower, art creativity is growing in the soil of local culture: it uses signs, grammar, semantics, emotions and intellectual associations understood only by members socialized in a common cultural environment.

I recall the first concert by Vladimir Horowitz back in Moscow: after having lived in exile for many decades: He played "Träumerei" (Dreaming) by Robert Schuman - a simple piano piece, often played also by children and learners. But when the TV - camera switched to the public, we saw touched faces, and tears running down the face of an elder man... How comes to this reaction? Because we, socialized and musically trained in our culture, understand the "message" between the lines of music, which evokes associations and deep emotions - not readable for foreigners. 
In fact such codification of information is very hard, time-efficient and partially impossible to be understood (even through learning effort) by members, socialized in another community. Only far future can show the impact globalization might have on art and culture and if its outcome will produce new global, transcultural societies.

The interesting question will be, if such a society might develop global citizens socialized together in one socio-cultural context and create so a new cultural identity.

\section{METHODS}

This essay investigates and questions... it is meant to raise awareness, curiosity and the lust on observation, rather then looking for an answer.

Lets look first at two different aspects: this is the cultural experience, which we receive unconsciously through our socialization in one socio-cultural contest. It is as the force which determinates us and shapes our mind and soul. The second force is intercultural experience, which we receive through interacting with members of other cultures and which we reflect consciously, to become real "experience".

\section{DISCUSSIONS}

\section{Cultural Experience}

"We understand only what we already know" states Gerhard Kubik, a leading ethnomusicologist and scholar, in his Essay: African and European Transculturation in the Environment of Expressive Culture. Whereby "knowing" means: recognizing what we learned - limited by our perceptional conventions, which are given through socialization and cultural determination.

Kubik looks at the problem of "understanding" foreign cultures - a point often given together with "globalization" - from the point of view of expressive arts. Referring to the time about 100 years ago in Europe, when Picasso, Braque and other artists discovered there love for African "art". The result of the analysis uncovers the behavior of these Europeans as typical and well known to people 
dealing with cultural comparism or acculturation. Thesis: when we meet another culture the first time, we describe the ununderstandable as "exotic"(or what ever words are existing in all the languages). In the 2. Phase we typically project our culturally bond thinking-patterns, perception patterns, values and ideas into the other culture. It might be the first positive try to understand it - yet it is of course a misunderstanding: The foreign culture becomes a place of projection of our own imagination, rooted in our culture, instead of in the other...

Similar in music it comes to the following, well known situation: we hear certain musical patterns, which elicit automatically something in us: they may let arouse emotions, remembering, thoughts - we believe, that we understand them (cause we "recognize" them)... But the fact is, that semantics of music or fine arts cannot be transferred into another culture. As well as recognized sounds, syllab or even words of one language don't man the same thing in another language. "Understanding means: recognizing something in the context and inside the border of a convention. Conventions are conditioned culturally. But conventions are transferable: understanding therefore is learnable." (G. Kubik, Zum Verstehen Afrikanischer Musik, Wien 2004, p.325).

Let's examine this thesis on the example of music and explain the problems which we face, when we talk about art in the context of globalization. "But music is a global language"! would argue some world-musicians... "we all can play together..." Though more then 100 years ago this idea of "global musical language" was a belief coming from the eurocentric view of the world, ethnomusicologists have constantly rejected such a view. Why? "There are many music - communities in the world, though not, probably, as many as there are speech - communities. Many of them are mutually unintelligible" (Seeger, 1941, in A. Merriam: Anthropology of Music, Evanston 1964, p. 10).

G. Herzog formulates it more precisely: “...one of the popular myths is, that music is a "universal" language... (But) our music... consists of a number of dialects, some of them are mutually unintelligible as found in language." (G. Herzog: 
Comparative Musicology, 1946, also in A. Merriam: Anthropology of Music, Evanston 1964, p. 10).

This result was proved through further investigations: Robert Morey did in Westafrika different experiments with respondents from another cultural circle. $\mathrm{He}$ described reactions on music from Schubert, Händel, Wagner a.o. The result was absolutely clear: "Western music is not recognized by the Loma of Liberia as expressing emotion... (p. 342). Musical expressions of western emotions do not elicit in Liberian boys any patterns of response...

Music, said to express emotion to an expert in music and emotion in western society, does not express emotion to auditors, whose musical and social training is different from that of the composer of the music. (p. 354). Merriam, Anthropology of Music, Evanston 1964, p.11).

My own experience is similar: In a Ugandan village church my friend from Slovenia offered to sing the Ave Maria from Bach-Gounod. When the music reached higher and higher and finally her soprano reached one of the "peaks", the whole crowd in the church exploded in common, loud laughter and clapping. I did not investigate, which associations they had, or what looked for them so funny: Evident is, that the perception was so different to ours, that the European nuns, living at the parish were now in opposite disturbed by not understanding how someone can behave so "not-understanding and respectless..."

So I was lucky, to get in my observation directly two answers which confirmed this theory: one of the African community and the other from the European community, both coming to the same result: not to be able to understand culturally bond information: "messages" (of the Music) on one side and "behaviors" (of the Ugandans) on the other.

Gerhard Kubik describes similar situations from both sides: Music is also becoming a projection - space for emotions. African songs with its temp, chords, melody and rhythmical characters are often experienced by listeners from another cultural world as joyful or sad. But those listeners are often very surprised, when they 
hear from their interpreter, that nothing like this was intended in the music or content of the words. Harp-Music of the Azande People, played from a lonely player in a full moon night, might easily drawn the occidental listener into emotional and romantic atmosphere... But this same listener would be shocked, to understand the text of what the musician was singing!

On the other side the African listener, visiting a free jazz concert was deeply convinced, that the female musician with the triangle was a "witchcraft doctor", or traditional African healer... Because he was able to judge, what he knew, what he "recognized" - thus this was more from a visual then from a musical point of view. Herskovits would call this "Reinterpretation": Reinterpretation is the typical behavior pattern, characteristic for the second phase of cultural intercourse, where we reinterpret - based on similarities in our own culture - recognized and selected material (compare: G. Kubik, Zum Verstehen afrikanischer Musik, Wien 2004, p.326 $-328)$.

But not only emotions, also our musical education and hearing expectations are projected in any sounds and music we listen to. Being conditioned in one musical system, our ear will ever tend to adjust the new listened material into our own hearing system: we will recognize it as something we "know", but "distorted" or "mistuned". So a person grown up with the occidental system of diatonic scale, will not be able to listen to the equiheptatonic scales from Mozambique, without "recognizing" a "mistuned diatonic scale". Or a Balinese with his ears trained in the 2 pentatonic scales of slendro and pelog will not be able of neutral listening to an African five tone scale, similar - but different! - to slendro... His ears will reinterpret the listened material, even when he is conscious about the problem. Which means, that a intra-culturally right perception is not experienceable for a person standing outside the cultural society. The later someone gets into contact with another musicculture, the harder it will be to get rid of these conditioned reflexes - up to the impossibility of "understanding". This "perceptorical change" of the listened material can not be corrected with will - power and brain effort, it lies much deeper in us. 
A traditional Balinese will also not be able to imagine, that European microtonal, atonal or chromatic music can elude emotions... ("cause they have to be expressed in the slendro or pelog scale..."). On the other side a European would never connect love and big feelings to the sound of a "distuned" bamboo flute... (it fits only for associations of nature, forest and pastoral motifs").

The composer and ethno-musicologist Colin McPhee lived in Bali for some years. He studied and collected music from Bali, but also observed the local people and studied their music perception. While playing for them some European classical music he got a response and reaction from his Balinese collegue, Nyoman Kaler. McPhee describes the following: "Since the piano had twelve tones to the g'ndér's five, the music I played held no meaning for Nyoman. Tourists brought back romantic tales of the Balinese taste for Bach, but this was quite impossible. Nyoman's reaction to Western music was typical. It was a complicated noise without order, tempestuous and baffling in its emotional climaxes, dragging on and on and leading nowhere. Your music is like someone crying, he said. Up and down, up and down, for no reason at all.

A simple tune on the white keys might catch his interest, but the harmony of the left hand ruined it for him. His ears could not filter the sound made by so many notes closely spaced". (C. McPhee, A House in Bali, London 1947, p. 45). In this context it is also useful to take a look at the clothing and the culturally encoded information herein. I often experienced being described by Ugandans as "muzhungu mooro" - a poor (or stranded) white man. Some looked full of pity to my wife: why she didn't manage to get a rich European? The reason were my shorts and sandals, or slippers. This clothes were worn by the local youth, by simple, poor and uneducated people. A studied person in Uganda gets a good job, good salary and is no longer in "need" to dress like this. It would dress a suite and a tie.

In my generation and socio-cultural context of an occidental intellectual from Germany, grown up with contemporary arts, political activism and the philosophy of Erich Fromm's book To Have Or To Be, rarely an liberal intellectual could put on the 
"conventional" clothes of the leading conservative society. This would be the clothes of the bankers and businessmen, the capitalists and "mainstreamers". Accordingly fashion clothes would show your not-educated or not-intellectual status and your dependency on the consume society instead of being an individualist. If you are an educated, intellectual and spiritual individual you don't need to care for your outside, or how people look at your outside. Through dressing you make clear, that you don 't want to be judged by what you "have“ (dressing), but by what you "are" (personality). So our "alternative" clothing which included jeans, working clothes, India-shirts or selfmade clothes expressed the refusal of the attributes of the leading society (conservative way of life, traditional customs and behavior) and should show self confidence in another way of life and individuality, but also disrespect to all nonreflected and conventional, to all mainstream. Up to now I dont wear suites and ties, but Ugandans of course read the absence of it my clothes in the contrary way.

In Africa/Uganda applies: if you are educated, intellectual and if you have a university degree, then you have to show or express this through your dressing: you range yourself into the community of educated people. Being studied, often means also having a job - being rich. In Africa there is NO contradiction between "being" and "having", as Fromm experienced from his background. His philosophy became only locally interesting... So the African book about this topic probably should be called: "To Be and To Have".

Wearing suite and tie, in fact means to many Africans to be „progressive, educated, not traditional“ - often it includes the refusal of traditional life - which is falsely synonymized with "old-fashioned" way of thinking and being a "remote villager". My Ugandan friends, though very exposed and educated were deeply surprised and excited when they met the executive director of a Chinese clothing factory, producing for many famous fashion brands, just wearing an old torn no-name T-shirt.

My Ugandan wife made the same experience, when I took her on the beginning of our relationship to a big music festival in Lugano/Switzerland, where I 
was invited. Being in the audience with just a short shirt and jeans I was greeted by other professors, who lectured and performed at the festival. Despite my simple clothing we evidently belonged to the same social group - which was at this time "unreadable" for my wife as a person with a Ugandan socio-cultural background and which made her to ask, why I didn`t also dress like them (as I heard from her some years later).

As we see: semantics in any field of life can have the opposite meaning in another culture. Already W. G. Haag (1960) postulated: "Art is not free. Artist are relentlessly grasped by the strongest but subtlest force that moves the world, that is, cultural determinism. Every change in the artistic taste of the times is engendered and nourished in a realm beyond the "minds" of artists. . . That place, of course, is the culture - the normative, stylistic, consistent behavior of which the artist is a participant and a partaker." (Merriam, Anthropology of Music, Evanston 1964).

Everybody is a "slave" of his culture: His world, his brain, his mind-set, his values, experiences and thinking - ways will ever remain subjective. I describe phenomenon out of my European radius - but I describe them with my European view and mind-set. Because in all things, in the choice of the words, in the kind of description, even in the ways of observing or in the selection of the material to be observed we are dependent on our cultural training. Even as observers we are not able to free our selves.

The book Dance around the Grave gives a wonderful insight into different death rites of the world. If writer, popular ethnologist Nigel Barley recalls there a situation where he met a Chinese ethnologist, doing research at the same remote tribe (Dowayo) in West Africa. Barley asked his college, what he thinks about their "exotic" death - rites and the connections between the Living and the Dead. Getting the answer, that there is absolutely nothing special on them, just all very normal and not even worth to be described, Nigel Barley understood, that his Chinese college would have been only interested, if there would be missing this connection between the Living and the Dead... Because they were similar to his own culture, the Chinese 
could not see anything special in them: it didn`t bring any new information for him (N. Barley: Tanz ums Grab). Of course: also for me as a European, the Balinese death rituals are extremely interesting, but for the local people they are nothing special, quite like the African rites of the Dowayo would be "quite normal" for the Balinese.

Andrea Korenjak states in her paper "Out of the words. The esthetical function of music in ritual contexts": The real universal consists in the fact, that music exists in every culture. We dont know any society, which would not have produced any kind of music. Like the universalia „LANGUAGE“ music also connects a social community as a medium of expression and communication. But the system of language and music can only understand a person socialized in this community or a person which has learned it. (in Barabakadse/Trinke (Hrsg.): Chancen und Schwierigkeiten des interkulturellen Dialogs über ästhetische Fragen, Wien 2016)

\section{Cross-Cultural Experience}

As stated in the introduction, intercultural experience can be received through interacting with members of other cultures, while reflecting consciously. Reflecting means: to be aware of our own perceptional limits and of the perceptional limits of the other side, to stay open-minded, observe and try to accept without filtering, reinterpreting and valuing. Only including a certain research of the sociocultural context and - if possible - life-sharing with members of the other culture, intercultural interacting can turn into a real intercultural experience. And this experience becomes a strong force to take us on, to help us to develop a wider understanding of the world cultures and their expressive results.

I carried out a series of listening experiments with different groups of respondents. Playing 4 musics from 4 different cultures, the respondents where asked to formulate what the feel and what they have understood. The musics were: (1) African Cultural Circle - Sub-Saharan Africa: Trumpets of Banda Linda. (2) European Cultural Circle: Interieur for Percussion Solo (H. Lachenmann). (3) Indo Asian Cultural Circle: Music for Rudra Veena. (4) Sino - Asian: Cultural Circle: 
Korean Classical Music. But the students would not know, what I present.

This experiment was done: (1) with Indonesian students of music, partially European Music, at ISI Denpasar in 2016. (2) with Czech students of music during the symposium for percussionists and composers in Trstenice/Czech in 2017. (3) with attendants of the conferency "Art, Creativity and Identity In The Global Era" at Program Pascasarjana (Postgraduate Program) of Institut Seni Indonesia (ISI) Denpasar, Bali, during my presentation in 2018.

All of the 3 groups were related to music as theorists, musicians or composers. All of them also were exposed and experienced in listening to musics from different musical cultures... Which means: their socio-cultural background of all my subjects was already another, then the one of the not-professional, not experienced listener in Moreys experiments. All the respondent background was extended with the experience of their profession.

The result of the experiment: (1) The Indonesian students: the musics caused sometimes laughter and were not understood or "accepted". Exception was made for the Indian music, which provoked associations of spirituality and was able to evoke emotions, e.g. "I like it". The Korean music caused silence and an attempt of interested listening. (2) The Czech community, which has attended the symposium based on own interest and paid for it: All were very curious and wanted to know what it is. Mostly they were not fascinated by the music, but by the sounds produced in it. With the question in the head: "how can I use it in my compositions (or integrate into my musical language)". There was no understanding of the material and more less no feelings. The biggest interest was given to the Korean Music. (3) The conference participants: there were 3 people to express their feelings or level of understanding, all of them cross-culturally experienced: The first two both recognized all the musical examples very precise, and why describing it, expressed their positive feelings towards the Korean resp. Indian music. The third, a dancer, thus exposed to other cultures and studying abroad, described exactly what he "liked" and why: it was the first and the last piece (African Music and the Korean Music), because "it has a clear 
rhythmical structure", which he can understand and - as a dancer - can dance and work with this music.

Although this was not a scientific experiment, we can see clearly how the social, cultural and professional background is the measurement for all the answers: The Indonesian students were not prepared and maybe not ready to receive such (musical) information. The had attended class with the subject "Musics of the World" because of their curriculum. The Czech students were searching for information, once they attended the symposium: their behavior shows high receptivity. And the attendants of the conference were very active and receptive. But in addition more skilled and exposed that the Czech students. So their responses reflect this fact: Like the Czech students they related their ways of hearing and adjusted their understanding to their profession, but additionally even described the Music in the answers given.

We see, that all spontaneous responds is arousing from our profession and knowledge. The way of listening is referring automatically to our background and perceiving the information from this point of view. Everybody in this "experiment" was listening to the sound - examples from his subjective point. But what all of them had in common: all were ready to listen and prepared to it (professionally, through the context, through earlier exposure...).

Let me come back to Allan Merriam: "It is evident, that another factor operates in this connection i.e. the factor of receptivity to understanding. Whereas it is to be accepted that members of an academic community in the West will be receptive, at least to a certain point, to be listening to and seaching for the values in the music of another culture, it is not so certain, that the introduction of Chinese opera into a hillbilly bar in Kentucky will meet with enthusiastic acceptance." (Merriam, Anthropology of Music, Evanston 1964, p.11). 
The Problem of Cross-Cultural Music Communication Depends both upon Understanding and, More Important, Receptivity to Understanding

I am convinced, that a second experiment, using only musics from different cultures but with a strong impact on rhythm, meter and pulse, will come to a totally different result. My prediction is, that all will feel somehow familiar with this music. And this only because I insert one element: The element of musical time structure (rhythm - meter - pulse).

Why we would feel familiar? Why we should understand something? Because this same element is found in all cultures: Rhythm = audiable mathematics. And mathematics are a phenomenon of nature - not of culture! Therefore it is valid for all humans in the same way... So we can recognize such things from and in all cultures. But: how the inner grammar and the musical concept inside the understandable musical structure is working, we will not be able to understand just by listening. Experiments with rhythms and drumming from Ghana were done on American universities by Koetting: They showed, that students might after some time play right, but still think and feel false. The musical terminology of the outgoing culture is mostly not translatable into the language of the receiving culture. Maybe similar to Balinese "Taksu"... So it needs to be experienced inside the cultural context - and this needs time!

My own experience, while learning with master Famoudou Konate is barely the same: Famoudou could not translate and communicate to us students how to listen, and to what to refer. It seems, some of our question were far away from his experience - radius and seemed to him strange and were simply not understandable. Therefor the answers given, did not provide any solution: we both were talking about something different, supposing, that our partner must know what we talk about, since we can produce the same mathematical sound structure. So only after long time some answers, emerging from our cultural horizon and the challenge of understanding the "attacks" coming from beyond our horizon, could be found and explain in a hybrid way a certain audio - experience. 
I have made many similar experiences watching "cross - cultural" concerts, where two or more percussionists played together. But independent on their high skills it happened regulary, that they improvised together meanwhile their feet were moving on different pulses or beats, sometimes even in different tempo.

I suppose, the reason is simple: Except the mental understanding and reproducing or/and improvising, there is another problem in the way. As mentioned above - the problem is our own cultural training, our own "being conditioned in our culture": It makes us to think, to behave and to feel how we do and to understand the way we understand (compare: "cultural experience"). So why do we do "intercultural projects"? Because we educate ourselves, and through it also our society.

Despite of all what i said in the chapter before, despite of all our cultural limitations, we - artists - are doing and working on intercultural or cross-cultural projects. We are trying out, we are examining this huge field of possibilities and we tend to expand our "first positive approach" of understanding - and misunderstanding - a foreign culture.

Allow me on this place to describe some of my own work and musical experience in this field: AfroBreak: African - European Music Project. AfroBreak is music for percussion trio as well as the name of this trio: All the instruments used where my own, self-made instruments (often used in our European contemporary compositions): I have a collection of very large drums and wooden instruments which I wanted to use in a special way, with music composed for it to bring our their rough and deep sound character. The creation of the instruments was based on African musical approach of "all is sounding“ and all can be an instrument in the right musical context. What I tried can be described of getting rid of European and African instruments, in order to create something new.

So the result is, that this is not African music, neither African instruments yet it might evolve associations in the listener. But its also not European music, yet we were playing on European contemporary music festivals. I was fascinated and wantede to use certain limited musical ideas: synchronicity of playing, 
complementary rhythmical material, the interweaving of independent patterns e. g. Influence came from the Mega - Architecture of the compositions of European contemporary composer I. Xenakis and from the long unisono compositions of West African Djembe soloists like Famoudou Konate or Mamady Keita.

The concept of the music created for AfroBreak melts African playing traditions with my own polymetrical motifs and uneven polyphonic rhythms. Creating the Musical concept $i$ used this things only as the "output - structure" over which then the whole musical expression is content in the improvisation. This is what I call: African "musiking" feeling - when you communicate directly and spontaneously with your moves and sounds. But it has almost nothing to do with classical African music! Rather i worked with what we call culturally conditioned hearing expectation - as described above. Using the experience from my own intercultural training and counting on the misinterpretation of the listened material by my audience - whether it is African or European - the result was as expected: The audience „recognized“ musical language, patterns, meters and so on, but all the time with a strange feeling, that something is not right, that it sounds false or "crucket" - yet in the same time it evidently fits together. By the time the listeners figured out, where $\mathrm{i}$ was leading them, by the time they understood finally, that there was an uneven meter construction, pretending (by how it was composed and played) to be straight and even (while grooving, swinging, and therefore be "danceable"), the music continued and took them to the next listening - adventure.

One wonderful experience, related to the topic of this paper, happened in a life concert. Masterdrummer Famoudou Konate attended our concert in Regensburg, Germany. Seeing him in the public we all were excited, and also longing for having him on stage. But we played a repertoire with almost all pieces having rhythms on uneven meters $(7,15,17,21$ or 23 beats) - not existent in the West African music tradition. Now we started with a piece, based on "psychological fraud": the rhythm "pretended" to be on 6 beats, yet it was only 5 beats. This result can be achieved, when we use something very similar to commonly known and recognizable musical 
cells, but count on the ability of the public to re-interpret things in order to understand them. In this case the musical syllab was a figure of 2.5 beats, but very similar (also through tempo) to the very common and in Malinke Music (West Africa) often used figure 03 beats. When, after a traditional African-like introduction this 2.5 beat-figure appeared solo (as the 3-beat-figure also often does in Malinke music), I saw the painful and disturbed expression in Famoudous face... He heard of course, that we are "not able to play the figure right and straight" and he must have hoped, that it will correct it and finally straighten up, before the whole thing collapses. But then into this humping rhythm came the second line - very straight and perfectly interlocking. Famoudous face showed enormous surprise, wondering and excitement: He understood that he was betrayed by his ears or brain, in the same time he understood that now he is totally lost but parallely realized, that the music should be like this. When then the third line came in, revealing, that the rhythm and the metrical structure of the music is "right" in this way (because "it fits, it works"), he started to enjoy: now he felt safe. Since there were fitting beats into a bigger unit and repetitive motifs coming again and again - no matter that it was after 10 beats - this music became understandable for him. He for sure found elements known to him from his culture.

That was my way, how to apply foreign cultural elements in my creations and how i tried to produce a not culturally - bond result. Or, better, a cross-culturally bond result. Which again gave my audience „open ears“ and new receptivity.

Through such experiences we learn to know about different principles of music, different rules, different sound-architecture, and musical instruments, different ways of playing and different music-philosophy.... But we also learn about different about cultural settings: beliefs, behaviors, food, unthinkable and unimaginable customs, religions, values, way of life, rituals and ways of thinking...

Through intercultural experience we grow in personality and develop our mind, we surely widen our ability of understanding. On the other side it also separates us a bit from our own society: we logically don't fit in any more so well...! 
And our "intercultural" creativity will need more time to be understood and taken by the own society.

Facit: intercultural musical experience or exchange is enriching us and causes interest, it is a great experience for all: the giver (creator) and the receiver especially in the field of learning, of learning to understand. It is an instrument of opening our mind: to make one seeing and hearing new things and reflecting old things...

\section{Beauty of the Mystery}

On my last teaching program at ISI Denpasar I wrote and later published a paper called: "Beauty of the Mysterious - about the impossibility to understand foreign cultures". In this Essay I philosophised about the diversity and community of different cultures. The following text is an excerpt from it:

Necessarily other cultures think and feel different about "sound-art" and use also different definitions for it. The European idea of „music“, coming from the antic Greek concept called MUSIKÄ cannot of course be valid for all other cultures. Evan here in Indonesia "Musik“ is used for occidental („western“) or European Music, meanwhile karawitan is the term for Balinese gamelan.

Because music and art are creations made by humans, I tried to question about and to search for common validity: what have all humans in common? If we concentrate on the very basics, and try to press out from all the given answers a certain "destillat“, we have to come to a simple, and commonly valid and accepted formula, which would include all the human beings.

Imagine a mathematician, who reduces a long formula, to get its essence, a short geniouse „pictogram“, describing complex phenomenon of our world in simple $E=m^{*} V$. „All should be as simple as possible - but not more then necessary“ (A. Einstein). The answer, resulting from such a concentrated examining might be: the instinct to live. Without doubt we live to live. For the sake of life: It is an Instinct, driven by an inner unconscious motor, not by daily will - decision. 
If we try to look at this life-instinct without any cultural context, separated from any background or philosophy, we will find out that it exists in the same way all over the world. It is valid for all cultures. It belongs to global mankind, to all human beings - without any difference in culture and race. We are born with it: it is not a product of our socialization or education. It might be the quintessence and the only thing all humans really share without cultural limits. Some might say, that also the sexual instinct or the eating instinct is common to all humans: Yes, but they are just parts of what I call the "living instinct": both are maintaining life: the one our present body, the other our life (the life of the family, the tribe, the nation, the humankind) for the future, while "reproducing" ourselves and seeding our genetical information for the future. Humans want to make sure to transit and be "there", to be present in the future, to multiply and so to survive in the world after.

It seems to be one of the very few things we all share through all the cultural contexts: All humans which live, do eat and mate. Yet there a hundreds of ways and truths how and what to eat and thousands of variants of sexual behaviors and habits - the basic act of receiving food into the body and the act of intercourse will ever remain biologically the same.

But all this phenomenon are rather also valid for the whole flora and fauna not explicitly for human beings. Which would mean, that there is probably nothing valid for all humans - except things rooted in the natural laws, things which we share with the whole nature.

And all things valid only for humans are culturally conditioned and not shareable. They are valid for limited communities of humans. We are born into a cultural community, which has its value-scales, world-images and ideas about life: That's what we share from the moment of our birth. According to ethnologist Nigel Barley, we even learn when and how to cry. A person cannot just escape its cultural identity to accept a foreign value-scale as equal to his. Anyway - it is a thesis, which remains to be proofed further... 
Globalisation is opening ways for influence, for inspiration. It can slowly help to create transculturation - a positive exchange of information in both directions. The result would be a transfer of conventions and successively the learning of understanding (the foreign culture). Finally: all civilizations went in there history already through transculturation (both ways) or mostly acculturation (one way):

It was a painful process, a process of wars and destruction, of colonization and foreign rule. A process of assimilation and acculturation, lasting centuries. Nowadays each German, Swedish or French is proud on the "achievements" of "our" culture: the law system, the religion, the arts: shortly on his Christian Hellenistic civilization.

But to be exact: nobody remembers or really knows "his“ Germanic, Celtic, Gallic or Slawic "culture" - because it died out long ago. It was sublimated into the culture of the former enemies, colonists and occupants. So the fact is: we are proud on the roman legal system, the greek culture and so on. All brought through the era of Roman ruling over Europe, The culture of the former enemies became ours...

And here in Bali we are proud on our Balinese gamelan, our Bali-Hindu religion, our musical instruments and all the big cultural achievement - rooted as well in culture of the former invaders from China and India. The same story like in Europe - and probably elsewhere in the world.

I suppose, that is the more precise reason why in the above described experiment some musical elements in the musics of India and China (Korea) were affecting the Balinese students. Chinese and Indian cultures are the two biggest influential powers in this part of Asia. And despite their difference different, both cultures are related to the local culture of Bali.

Of course not only through war, slavery, occupation or colonization local cultures got extincted and new cultures emerged, but also through long-time influence from inside: "cultural colonization" can be carried out very quietly, but instantly. 
The photographer G. Schuh described 80 years ago ethnographically his journey through South-East Asia and all the photographs taken there: „Chinese people settle everywhere, adjust to any situation, multiply and intermix. But in all quietness they continue in their religion, their opium, their language and their own moral. In the mixed children lives the Chinese kind. In this way they colonize, polite smiling, Burma, Siam, Indochina, Malaya, the whole East Indian Archipel and the best part of the islands in the pacific ocean. A quiet and not stoppable ethnical migration of the present time, on which even modern wars have only small influence."

\section{Strong Cultures will ever Survive}

In this way the Mongolic tribes, which ruled centuries over China, were slowly sublimated into the Chinese culture - not in opposite! To rule, they needed to adjust: in this way they overtook and adjusted themselves to the Chinese culture, which - in contrary the own oral culture - already used written language and printing.

Two hundred years ago those things were already described by the Geographer Berghaus (1797-1884): „Foreign nations stepped in China up to the top of the regiment, last the Mongols, the Manichers, which are ruling presently. But those foreigners did not manage to change anything on the inner politics of the empire; The rulers from this foreign ethnical tribes were not able to introduce their habits and conventions on the Chinese throne, but became in opposite Chinese themselves, overtaking the ways of thinking and the Chinese education." (Heinrich Karl Wilhelm Berghaus: Grundriss der Geographie in fünf Büchern).

Religion is of course the biggest carrier and promoter of culture and also it fastest transporter... in religion the culture is rooted and with it uprooted. That's why we find people of different background and ethics - through Southeast Asia, Central Asia, Middle-East, Northern Africa up to Western Africa - meeting them selves, reading the same books in the same language, believing the same and behaving similar, eating, dressing and praying the same, singing the same songs and playing 
similar instruments in similar style. And sometimes even speaking the same language - while feeling familiar at Dubai or Istanbul airport, coming maybe sometimes from the same pilgrimage in Mekka.

But that is also, why for instance our, through Hindu religion connected Balinese, have managed to keep their own strong culture expressed in music, theater, dance, religion and omnipresent daily habits in the surrounding of a different culture and its influence.

\section{CONCLUSION}

If my points are right, we have to come to two conclusions: (1) We have to protect local cultures from being eaten from and sublimated through other cultures; (2) We have to accept the differences in cultural life and social behavior of others, to learn about it and to educate our selves interculturally. Then our own culture will grow and develop through influence of other cultures, brought through artists and scientists from our own society as a progression of our culture.

If we become ready to give up own "truths", we will be able to accept foreign beauty: foreign order, esthetics and values will become just another version of truth. G. Bateson said: Information is the difference, which makes a difference! Following: mainly in intercultural experience we receive real information in Bateson's sense. And this provokes in a person that it has to change and to expand its point of view... Therefore we can say: Intercultural experience is true human education.

May all the gods of all religions and cultures help us to stay stunning and accept the diversity nature and humans have created: To accept and recognize humble that we don't understand - and therefore be able to admire the mysterious. Einstein said: "The most beautiful thing we can experience is the mysterious. It is the source of all true art and science. To whom the emotion is a stranger, who can no longer pause to wonder and stand wrapped in awe, is as good as dead; his eyes are closed." 


\section{REFERENCES}

Barabakadse, D; Trinke J (Hrsg.). 2016. Chancen und Schwierigkeiten des Interkulturellen Dialogs uber aesthetische Fragen. Lit Verlag Wien.

Barley, N. 2000. Tanz ums Grab. Munchen: dtv Munchen.

Bateson, G. 2018. "Information Is the Difference", internet source.

Berghaus, HKW. 1843. Grundiss der Geographie in funf Buchern.

Einstein, A. 2018. "All should be as Simplel as Possible - but not more than Necessary", internet source.

Herzog, G. 1946. Comparative Musicology, 1946, in A. Merriam: Anthropology of Music, Evanston Northwestern University Press.

Kubik, G. 2004. Zum Verstehen Afrikanischer Musik, Wien.

McPhee, C. 1947. A House in Bali, London.

Merriam, A. 1964. Anthropology of Music, Evanston Northwestern University Press.

Schuh, G. 1954. Inseln der Gotter. Buchergilde Gutenberg, Frankfurt.

Seeger. 1941 in A. Merriam: Anthropology of Music, Evanston. 